\title{
The Concept of Pedagogical Content Knowledge (PCK): Recognizing the English Teachers' Competences in Indonesia
}

\author{
Ummi Kultsum \\ Faculty of Education, Science, Technology and Mathematics (ESTEM) \\ University of Canberra, Australia. \\ Ummi.Kultsum@canberra.edu.au \\ ummikultsum@uinjkt.ac.id
}

\begin{abstract}
This article discusses the concept of Pedagogical Content Knowledge (PCK) in Indonesian school context. The PCK is described as the basic skill for teachers in order to develop their teaching quality and strategy. The focus of the discussion is in the English teaching strategy in Indonesia. The review found that PCK on English teachers in Indonesia needs to be improved especially in pedagogical knowledge of teaching strategy and knowledge of learners. It is recommended that the control and evaluation from government and other stakeholders would maintain the quality of teachers. Furthermore, the competencies would be more magnificent when teachers emerge the dedication and commitment in their profession.
\end{abstract}

Keywords-PCK concept; content knowledge; pedagogical knowledge; English teacher's competences

\section{INTRODUCTION}

Pedagogical content knowledge (PCK) was first introduced by Shulman in 1986, and described as the synthesis of teachers' subject matter knowledge with their pedagogical knowledge. PCK is the integration between content knowledge and pedagogical knowledge of the teachers in delivering a subject matter in accordance to the ability and interest of learners [1]. However, some studies identified the PCK is the knowledge of content subject matter (CK), pedagogical knowledge (PK), and knowledge of learners [2], [3], [4]. Thus, the PCK attends to lead teacher in solving student's misconceptions about the subject that they learn.

Many studies have examined the impact of PCK on the quality of teaching and learning in the area of mathematics and science [5], [6], [7]. However, the study in the field of teaching English as a second/foreign language is still rare [8]. Therefore, this paper will focus on pedagogical content knowledge and its application in the teaching English in Indonesian context.

In Indonesia, the concept of PCK is categorized as teachers' competencies. Some training is conducted in order to develop this ability. Further, the government regulates it in the rule of Ministry of National Education (MoNE) number $16 / 2007$. Some studies of PCK in teaching EFL in Indonesia are conducted to measure and to prove to what extent the PCK of the teachers influence students outcomes [9], [10], [11],
[12]. Hence, it is necessary to identify what are the significant issues related to English teachers PCK in Indonesia.

\section{PCK; DEFINITION AND CONCEPT}

Pedagogical content knowledge (PCK) has been a significant topic to be discussed in the teaching quality since decades. Shulman (2004) bold that PCK is a combination between a specific subject of subject matter knowledge and pedagogical knowledge that is important for teachers to be possessed. These two domains are integrated. Subject matter knowledge or known as content knowledge (CK) is the knowledge of the specific topic, which teacher requires teaching it. For example, English teacher should have the ability of understanding on English materials and capable of delivering it to her/his students. This domain becomes a prerequisite knowledge in PCK Concept.

Another domain is pedagogical knowledge (PK). Shulman (2004) stated that PK involves the teaching principals and strategies that are applied in the classroom management and organization. Furthermore, the PK also includes teacher's knowledge of students learning, assessment and education purposes [13]. The integration of two domains can be described with the figure as follows [14].

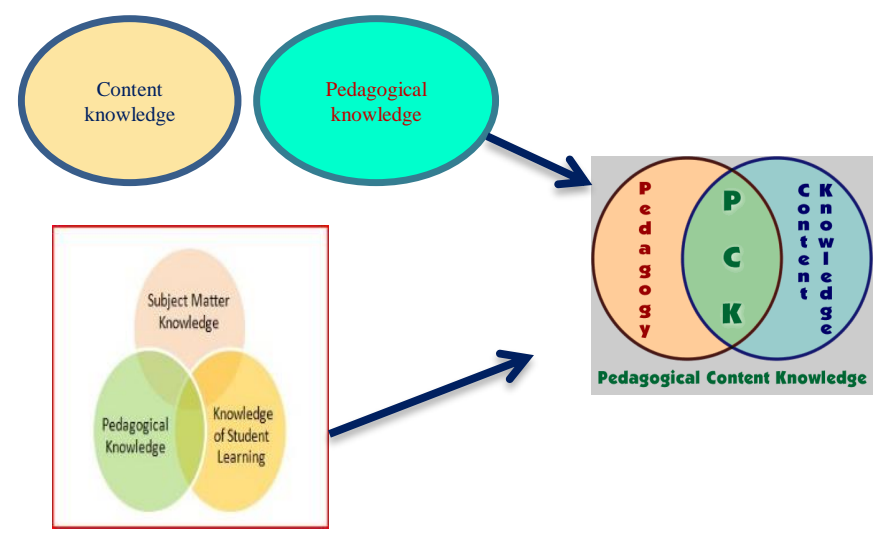

Figure 1 Integration of two domains 
As the integration of both $\mathrm{CK}$ and PK, PCK is designed as the knowledge indicates teachers' capacity to transform the content knowledge, and suits to different learners' ability and background [15], [16], [17]. Therefore, a teacher with good PCK domain will produce a decent teaching quality and students' achievement. Ashton in Cochran stated that [18]:

'Pedagogical content knowledge is a type of knowledge that is unique to the teachers, and is based on the way teacher relate their pedagogical knowledge (what they know about teaching) to their subject matter knowledge (what they know about what they teach). It is the integration or the synthesis of the teacher's pedagogical knowledge and their subject matter knowledge that comprises pedagogical content knowledge (PCK)'.

According to Shulman, PCK is part of teachers' professional criteria. The same idea also delivered by Darling-Hammond and Stronge. According to them, some principles of teachers' professionalism might give positive correlation into students' achievement. The criteria such as general academic ability and intelligence, subject matter knowledge (content knowledge), certification status and knowledge of teaching learning (pedagogical content knowledge) are the current factors for students to meet their positive outcomes [19], [20].

\section{CONTENT KNOWLEDGE (CK)}

The content knowledge is the core knowledge of teacher in particular subject and specific content area. For many years, some researchers focused on the discussion that teachers' content knowledge impacts students' achievement. Those studies found that the lack of teachers' knowledge should find the difficulties of the teaching-learning process [21], [22], [23], [24]. Darling Hammond stated that teachers' content knowledge is the fundamental requirement for an effective teaching [25]. Furthermore, content knowledge of teachers influences the teaching-learning process, and it makes the substantial effect for learners' achievement.

Due to English teaching, a study conducted in 2016 included some teachers across language speaking countries such as Canada, New Zealand, and the USA. It found that a reading progress at the school could be the failure with the lack of an effective teaching [26]. The study was focused on the reading for learners with dyslexia. At this stage, they stressed the teachers' content knowledge or teachers' understanding of reading concept, which has a significant influence on learners' understanding of learning the English language. The content knowledge of teachers may improve their initiative in the teaching process. It also developed more teachers' attention to developing their knowledge.

In Indonesia context, content knowledge is one of an essential requirement for teacher qualification. It is set in the Ministry of National Education (MoNE) rule No.16 year 2007 stated that teachers must have a minimum education qualification diploma four (D-IV) or Bachelor (S1) study program under the subjects taught / of teaching, and obtained from accredited study programs [27].
Besides an academic requirement, the government also develops some programs to maintain teachers' content knowledge. For instance, a Pendidikan dan Pelatihan Profesi Guru (PLPG) or Education and Professional Training of Teachers is the training that held by MORA and MoNE to enhance the professionalism of teachers which included a certificate afterward. This training has a variety of duration from 9 days until 165 days that it depends on the skills need of the teachers [28]. Since the training stimulates teachers' knowledge of materials and pedagogy, they will have more opportunity to succeed learning process in the classroom.

\section{PEDAGOGICAL KNOWLEDGE (PK)}

Pedagogical knowledge (PK) is another element inside PCK. The knowledge is related to the ability of teachers in delivering the effective teaching and learning atmosphere for all learners. Shulman says that pedagogical knowledge is the knowledge, theory, and belief about the act of teaching and the process of learning, which it figures the teacher's approaches in delivering a subject in the classroom. The learning process also provides all activities from developing the materials, classroom management, learning habit, problem-solving, methodology, strategy, and assessment [29]. The successful of these events determines the improvement of students learning outcomes.

The experience in teaching would be a factor for teachers in developing the aptitude of PK. For instance, Gatbonton has tried to compare between experience and novice ESL teachers in their pedagogical knowledge. He found that the pedagogical knowledge between the two groups is similar. However, the experience teachers have the more detailed pedagogical knowledge, especially in recognizing students' attitudes and behaviours [30]. It means that teachers' educational background provide the development of teachers knowledge in teaching a subject. Further, the experience will strengthen the knowledge to make teachers more professional in their field.

From the Gatbonton study, it could be concluded that teachers' training, which they gain in undergraduate study, may develop the pedagogical knowledge. It was been proved by Hudson. His study had been held in Australia with math and science pre-service teachers from nine different universities. Those were gathered to be treated and mentored in a specific subject area. The mentee then being observed, reviewed, and evaluated on their overall teaching ability. The study revealed that coursework, mentoring and fieldwork for pre-service teachers during undergraduate have influenced their pedagogical knowledge [31], [32].

The two studies considered that the durations of teaching experience and the training of teaching are necessary to support teachers' quality. Teachers' training develops teachers' knowledge in mastering the subject. The training also encourages the teachers to increase teachers' quality in the teaching ability. Further, the experience teachers have more opportunity in developing their professionalism. The 
experience teachers are used to face many situations in the process of instruction. Therefore, they might establish their teaching strategy in some different atmosphere of teaching. Moreover, the experience teachers also have more chance to face many characters of students. Thus, they may have more knowledge to understand students' learning problem compare to the novice teachers.

\section{THE ENGLISH TEACHERS' PEDAGOGICAL CONTENT KNOWLEDGE (PCK)}

Since the PCK integrates specific content knowledge and pedagogical knowledge, an English teaching subject becomes one of the specific issues that could be discussed. Some studies have involved seeing English teachers PCK and how does it work in teaching learning process.

Research, conducted by Liu, discussed the pedagogical content knowledge (PCK) as a case study on the elementary teacher [33]. The research setting is in the US, and the candidate is a native English teacher. Based on Shulman theory, Liu adapted the understanding of PCK as the combination of subject and pedagogy. The research gave the insight into how teacher elaborate the subject matters into well organised, interesting, and accommodate students' needs and ability.

At this stage, Liu separated between subject matter and pedagogy in the concept of PCK. People with ESL content knowledge would be able to teach because CK is the ability that possesses by the teacher. However, a teacher with PK would have more opportunity to have the variety of teaching strategies, which the learning process would run efficiently.

In the study, PCK is categorised on; subject matter knowledge, pedagogical knowledge, knowledge of learners, and knowledge of teaching context. However, for the study, the participant was emphasized on pedagogical knowledge only. The instruction materials did not follow the syllabus. Therefore, the teacher makes his/her philosophical beliefs that cause different nature of teaching. This learning model became uncontrollable and teachable.

The PK will be gain better through experience in teaching in the real classroom. The extended period of teaching will create the more professional teacher in their field. Therefore, the teacher candidate needs to acquire teaching skills in teaching education program, and they require more practice in the real classroom rather than the only read and learn from the scratch.

Another qualitative study conducted by Irvine-Niakaris and Kiely explored about PCK that supports teaching English as a second language (L2) especially in reading skill [34]. The research was cantered on teacher's knowledge about reading instruction (KARI) and knowledge about the text (KAT). KARI is the ability that needs to be possessed by the teacher to build reading teaching strategy. Meanwhile, KAT is the ability for the teacher to understand the context of the text, so, he/she may create the schemata for learners to understand the text as a whole.

They stated that teacher should have mental cognition including how to think, know, and believe in complex nature of teaching to enhance the effectiveness of teacher education. This would be considered as the appearance of PCK. The PCK includes in teachers' understanding of subject learners, curriculum, context, and pedagogy Subject content and pedagogy are central in identifying teacher's knowledge in applying the variety of teaching and learning context.

The PCK is applicable in teaching reading L2 in the classroom practice. Therefore, the study is focused on reading comprehension that included the understanding of word recognition, morphology, syntax, and connecting to the main idea. This research considered that the bottom-up model was more significant to be chosen since it focused on the word level. The word level may lead students to recognise the words; therefore, they may have more chance to understand more about the text. On the other side, top-down model invites learners to make a prediction which it would make students able to recognise the main idea.

At the teaching process, they applied pre-reading, while reading, and post-reading technique. In the pre-reading, teacher stimulates students' thinking before they read the text. The teacher invites students to build the information about the theme that they are going to read. This would track students read easier. In a while reading session, teachers as guidance in inviting students' comprehension through prompting, probing, and modelling.

The PCK, at this stage, accommodate both pedagogy and content knowledge. In pedagogy, teaching reading focuses on the instructions and teaching strategies; while, content knowledge is focused on text genre and reading text constructions.

The research revealed that teachers' KARI 'reflected their cognition study. They could manage the organisation of teaching process from pre, while, and post reading stages. Regarding the teachers' KAT, all teachers demonstrated the capacity in analysing the text and comprehension questions. The function covers aspect detail such as vocabulary, paragraph structure, and text purposes.

\section{PCK AND ENGLISH TEACHERS' COMPETENCY IN INDONESIA}

In Indonesia, there are also some studies of PCK in teaching English [35], [36]. For instance, a study conducted by Faisal discussed the concept of PCK in English subject in Indonesia. The study focused on teaching English based on the curriculum year 2013 (K 13) [37]. He explored how the PCK concepts matched to the curriculum, specifically in the English subject. 
In teaching English, PCK took the necessary rules because it constitutes teachers' ability in subject matter and the way they transform it to the learners.

Based on the regulation of Ministry of National Education (MoNE) number 16/2007, PCK is noticed as Pedagogical competences. It is categorised into four specific groups including competency of pedagogy, professional, personal, and social. Pedagogy competence is the ability to manage an instructional practice involving students. Professional competence is the ability to understand the subject matter properly. Personal competence is the ability of teachers to develop and maintain their good character in order to be a model of the learners. Social competence is competence to communicate and interact with pupils, colleagues, learners' parents, and surrounding community efficiently and assertively.

The four components are necessarily needed for English teachers in Indonesia. The elaboration of the component will develop teachers' professionalism. Thus, the quality of the teaching can be maintained. The competency of pedagogy, professional, personal, and social are integrated into PCK domain as follows. First, PCK domain of knowledge of curriculum includes in the competency of pedagogy. In pedagogy knowledge, the teacher considers to develop the learning curriculum and mention the principles of the instruction. Teachers also need to understand the aims of the instruction and what the possible strategy to applicate the subject in the class. Other pedagogy knowledges are also related to teachers' ability in selecting suitable learning experience and instructional objective and develop indicators and instrument of assessment. In professional competency PCK concerns on teachers' understanding standard and essential competencies, and learning objectives. At this stage, in understanding curriculum, an English teacher should acquire between concept theory and practical matter. In other words, they should understand how to develop instructional practice from planning to evaluation.

Second, PCK of knowledge of subject matter integrates with teachers' professional competence. The mastery of subject matter in language includes teachers understanding on language knowledge such as linguistics, discourse, sociolinguistics, and strategy. Further, teachers also need to master the English communication effectively.

Third, PCK of knowledge of learners integrates with pedagogy and social competencies. At this stage, teachers should recognise and understand student's potential and ability. Thus, they may find and analyse student's difficulties in learning English. To achieve this, the teacher needs to develop their effective, emphatic, and tactful communications to the learners. This, of course, requires a social competence where teachers' behaviour is considered. The social competence also stresses on equality, objectively and equitably in treating students in the classroom. Knowledge of learners is also related with students' cultural approach. It is the ability of teachers to teach English based on students culture.

Finally, PCK of pedagogical knowledge integrates with pedagogy and professional competencies. It is related to the teacher's learning organisation in the class, which invites their creativity in transforming the materials. At the conclusion, the PCK concept endorses the teaching strategies, methodologies, and techniques.

However, some studies in Indonesia reflected that the PCK of English teachers is needed to be improved. For instance, a qualitative study conducted in Banda Aceh found two problems that need to be considered by teachers in developing their PCK [38] Based on his observation; those teachers are still weak regarding pedagogical knowledge and knowledge of learner's category.

Although the teachers teaching strategy were in the context and the right teaching tracks, the creativity of teaching approaches still needed to be developed. Further, the knowledge of learners tended to be poor since the teachers did not show the engagement between the instructor and the students. They put lack attention and interaction to solve students 'problems and misconceptions in understanding the subject. Therefore, this weakness indicates the low of learning effectiveness.

The obstruction in developing good PCK for English teachers in Indonesia may face the solution in some strategy. First, the control from government and schools' stakeholders is necessary to maintain the quality of the teachers. However, it also needs to be balanced with the other support including school and class facilitation and financial. Second, the most important maintaining of teacher' PCK is the teachers themselves. The high teachers' dedication and commitment in teaching the students tend to increase the quality of teaching [39]. Therefore, as the main role of teaching and learning process, teachers need to develop and elaborate their skill of teaching and have the huge responsibility to reach the aim of the teaching goals.

\section{SUMMARY}

To sum up, content knowledge and pedagogical knowledge are significantly needed in teaching English. Pedagogical content knowledge (PCK) can develop teachers believe in teaching English into a better way. PCK in English teaching would help teachers to understand how to explore their content knowledge and how to deliver it into a good instruction. The teachers' ability such as professional, personal and social are elaborated into PCK domain. The knowledge such as subject matter, curriculum, teaching strategy, and learners' learning will be an important element to be possessed by the teachers in order to maintain students' learning achievement.

In Indonesia, PCK is known as pedagogical competencies. The government put it as a serious matter to (or "intending 
to") maintaining teachers' professionalism. Therefore, it has been regulated by Ministry of National Education (MoNE) number 16/2007. Some moves to develop PCK domain on English teachers in the schools are conducted to apply the regulation. However, some issue like students' approaches, teaching strategy, and teaching creativity are the significant matter to be noticed. This problem would be solved with the proper control of stakeholders and the will of teachers themselves. Thus, within the time of teaching and learning process, the obstruction can be resolved.

\section{REFERENCES}

[1] Shulman, L. S. (2004). Knowledge and teaching: Foundations of the new reform. San Francisco, Jossey Bass.

[2] Liu, S. (2013). "Pedagogical content knowledge: A case study of ESL teacher educator." English Language Teaching 6(7): 128.

[3] Gess-Newsome, J., et al. (2016). "Teacher pedagogical content knowledge, practice, and student achievement." International Journal of Science Education: 1-20.

[4] König, J., et al. (2016). "Teachers' professional knowledge for teaching English as a foreign language assessing the outcomes of teacher education." Journal of teacher education 67(4): 320-337.

[5] Van Driel, J. H., et al. (2002). "The development of preservice chemistry teachers' pedagogical content knowledge." Science Education 86(4): 572590.

[6] Gatbonton, E. (2008). "Looking beyond teachers' classroom behaviour: Novice and experienced ESL teachers' pedagogical knowledge." Language Teaching Research 12(2): 161-182.

[7] Gess-Newsome, J., et al. (2016). "Teacher pedagogical content knowledge, practice, and student achievement." International Journal of Science Education: 1-20.

[8] Marie Evens, J. E., and Fien Depaepe (2016). "Pedagogical Content Knowledge in the Context of Foreign and Second Language Teaching: A Review of the Research." Porta Linguarum: 15.

[9] Amin, M. (2015). "What Makes Teachers of EFL Professional or Unprofessional." Jurnal Pendidikan Humaniora (JPH) 2(4): 294-303.

[10]Faisal (2015). "Pedagogical Content Knowledge in Indonesian English Language Teaching." Asia Pacific Journal of Multidisciplinary Research Vol. 3 No.5: 8.

[11]Hartati, T. (2016). "PCK (Pedagogical Content Knowledge) bagi Mahasiswa S-2 Pendidikan Dasar dalam Rangka Implementasi Kurikulum 2013." SOSIOHUMANIKA 9(1).

[12] Ibrahim, B. (2016). "PEDAGOGICAL CONTENT KNOWLEDGE FOR TEACHING ENGLISH." English Education Journal 7(2): 155-167.

[13] König, J., et al. (2016). "Teachers' professional knowledge for teaching English as a foreign language assessing the outcomes of teacher education." Journal of teacher education 67(4): 320-337.

[14] Shulman, L. (1987). "Knowledge and Teaching - Foundations of the New Reform." Harvard educational review 57(1): 1-22.

[15]Faisal (2015). "Pedagogical Content Knowledge in Indonesian English Language Teaching." Asia Pacific Journal of Multidisciplinary Research Vol. 3 No.5: 8.

[16]Xu, W. (2015). "Exploring ESL/EFL Teachers' Pedagogical Content Knowledge on Reading Strategy Instruction." English Language Teaching 8(11): 155 .
[17] König, J., et al. (2016). "Teachers' professional knowledge for teaching English as a foreign language assessing the outcomes of teacher education." Journal of teacher education 67(4): 320-337.

[18] Cochran, K. F., et al. (1993). "Pedagogical content knowing: An integrative model for teacher preparation." Journal of teacher education 44(4): 263-272

[19]Darling-Hammond, L. (2000). "Teacher quality and student achievement." Education policy analysis archives 8: 1.

[20] Stronge, J. H. (2007). Qualities of effective teachers, ASCD.

[21] Darling-Hammond, L. (2000). "Teacher quality and student achievement." Education policy analysis archives 8: 1.

[22] Loewenberg Ball, D., et al. (2008). "Content knowledge for teaching: What makes it special?" Journal of teacher education 59(5): 389-407.

[23] Ozden, M. (2008). "The Effect of Content Knowledge on Pedagogical Content Knowledge: The Case of Teaching Phases of Matters." Educational sciences: theory and practice 8(2): 633-645.

[24] Washburn, E. K., et al. (2016). "Preservice teacher knowledge of basic language constructs in Canada, England, New Zealand, and the USA." Annals of dyslexia 66(1): 7-26.

[25] Darling-Hammond, L. (2008). "Teacher learning that supports student learning." Teaching for intelligence 2(1): 91-100.

[26] Washburn, E. K., et al. (2016). "Preservice teacher knowledge of basic language constructs in Canada, England, New Zealand, and the USA." Annals of dyslexia 66(1): 7-26.

[27](2007). Peraturan Meneteri Pendidikan Nasional (Education Ministeria Regulation); Standar kualifikasi akademik guru (Teachers academic qualification standard).

[28](2008). Peraturan pemerintah Republik Indonesia tentang Guru (Indonesian Government Regulation on Teachers). 194.

[29] Hudson, P. (2007). "Examining mentors' practices for enhancing preservice teachers' pedagogical development in mathematics and science." Mentoring \& Tutoring 15(2): 201-217.

[30] Gatbonton, E. (2008). "Looking beyond teachers' classroom behaviour: Novice and experienced ESL teachers' pedagogical knowledge." Language Teaching Research 12(2): 161-182.

[31]Hudson, P. (2007). "Examining mentors' practices for enhancing preservice teachers' pedagogical development in mathematics and science." Mentoring \& Tutoring 15(2): 201-217.

[32] Moradkhani, S., et al. (2013). "English language teacher educators' pedagogical knowledge base: The macro and micro categories." Australian Journal of Teacher Education 38(10): 8.

[33] Liu, S. (2013). "Pedagogical content knowledge: A case study of ESL teacher educator." English Language Teaching 6(7): 128.

[34] Irvine-Niakaris, C. and R. Kiely (2015). "Reading comprehension in test preparation classes: an analysis of teachers' pedagogical content knowledge in TESOL." TESOL Quarterly 49(2): 369-392.

[35] Setiadi, R. and B. Musthafa (2013). "Pedagogical Content Knowledge (PCK) and Teaching Performance of Indonesia's Language Teachers at the Aftermath of Teacher Certification Program: A Case of Indonesia." Asia-Pacific Collaborative Education Journal 9(2): 69-78.

[36] Munifatullah, F., et al. (2016). "Indonesian EFL Teachers Professional Knowledge Development during Their Participation in TSG: A Case Study." English Language Teaching 9(8): 62

[37]Faisal (2015). "Pedagogical Content Knowledge in Indonesian English Language Teaching." Asia Pacific Journal of Multidisciplinary Research Vol. 3 No.5: 8.

[38] Ibrahim, B. (2016). "PEDAGOGICAL CONTENT KNOWLEDGE FOR TEACHING ENGLISH." English Education Journal 7(2): 155-167.

[39] Amin, M. (2015). "What Makes Teachers of EFL Professional or Unprofessional." Jurnal Pendidikan Humaniora (JPH) 2(4): 294-303. 